\title{
Konsep Pendidikan Bagi Anak Dengan Problematika Belajar
}

\author{
Maskun dan Mufidul Abror \\ Universitas Islam Lamongan \\ Email corresponding author: maskun@unisla.ac.id/ mufidulabror1986@gmail.com
}

\begin{abstract}
ABSTRAK
Pendidikan adalah hak asasi manusia, oleh sebab itu pendidikan harus dapat di nikmati oleh semua waga Negara Indonesia. Anak dengan problema belajar juga memiliki hak yang sama dalam memperoleh pendidikan yang layak. Anak dengan problema belajar mencakuo anak dengan keubutuhan khusus, hal ini berarti bentuk pelayanan pendidikan yang di berikan juga khusus. System pendidikan bagi anak kebutuhan khusus saat ini lebih di wujudkan dlaam bentuk atuan pendidikan luar biasa. Namun terdapat kecenderungan system pendidikan yang mengarah pada konsep mainstreaming yang sangat fleksibel. Sejalan dengan konsep ini, muncul model pelayanan pendidikan luar biasa yang di sebut model inklusi, yang menekankan keterpaduan penuh, menghilangkan label anak (normal atau tidak norma) dengan prinsip education for all.
\end{abstract}

Kata Kunci: Pendidikan, problema anak belajar

\begin{abstract}
Education is a human right, therefore education must be enjoyed by all Indonesian citizens. Children with learning problems also have the same rights in obtaining a proper education. Children with learning problems include children with special needs, this means that the form of educational services provided is also special. The education system for children with special needs is currently more manifested in the form of special education rules. However, there is a tendency for the education system to lead to a very flexible mainstreaming concept. In line with this concept, an extraordinary education service model emerged called the inclusion model, which emphasizes full integration, eliminating the label of children (normal or not) with the principle of education for all.
\end{abstract}

Keywords: Education, children's learning problems

\section{PENDAHULUAN}

Istilah anak dengan problema belajar dalam tulisan ini di gunakan untuk menampung berbagai pandangan, pengertian dan defenisi serta klasifikasi tentang anak berkebutuhan khusus, termasuk di dalam nya anak berkesulitan belajar baik dalam pengertian umum maupun spesifik. Serta jenis kategori lain yang menybabkan anak mengalami problema dalam belajar. Penulis lebih memilih istilah problema belajar daripada kesulitan belajar di karenakan untuk tujuan fungsional yaitu memudahkan para praktisi pendidikan di lapanga dalam memeberikan pelayanan pendidikan yang sesuai.

Secara filosofis pendidikan merupakan Hak Asasi Manusia, sejalan dengan UUD 1945, sesungguhmya pendidikan bersifat terbuka, demokratis, tidak diskriminatif dan menjangkau semua warga Negara tanpa kecuali. Dalam konteks pendidikan untuk semua anak-anak yang mengalami kelainan fisik, intelektual social emosional, gangguan motorik atau anak berkebutuhan khusus (ABK) merupakan warga Negara yang memiliki hak sama untuk menikmati pendidikan seperti warga Negara yang lain. Untuk itu pemikiran dan realisasi kea rah upaya memenuhi kebutuhan pendidikan bagi mereka terus dilakukan. 
Anak dengan problema belajar merupakan salah satu bagian dari ABK. Mereka pada umumnya di kenal sebagai anak berkesulitan belajar, anak lamban belajar, anak malas, anak bodoh dan lain-lain. Menurut para ahli, prevalensianak-anak dengan problema belajar cukup tinggi, ada yang memperkirakan berkisar antara 1-3\%.

Di Negara berkembang seperti Indonesia, prevelansi anak dengan problema belajar di perkirakan lebih besar, penyebabnya adalah masih cukup tingginya angka kurang gizi pada ibu hamil, bayi dan anak, diare, penyakit persalinan serta infeksi susunan saraf pusat pada bayi. Gangguan atau kondisi di atas sering kali mengakibatkan terjadinya kesulitan belajar. Untuk mengatasi kesulitan dan atau problema belajar yang di hadapi serta untuk meningkatkan potensi yang dimiliki mereka memerlukan pelayanan khusus, pelayanan khusus tidak harus dalam satuan pendidikan khusus.

Kurangnya pelayanan pendidikan yang optimum bagi peserta didik dengan problema belajar juga akan berdampak pada angka tingginya angka kebodohan yang juga berdampak pada kurangya pelayanan pendidikan. Dengan memperhatikan berbagai pemikiran dan temuan lapangan ebag aimana yang telah di jelaskan di atas di pandang perlu untuk terus menerus mensosialisasikan kepada masyarakat tentang anak dengan problema belajar. Tulisan ini di maksudkan untuk menjadi salah satu sumber informasi tentang anak dengan prolema belajar.

\section{KAJIAN KOSEPTUAL}

Ada beberapa teori yang bersangkutan dengan tulisan ini, dan penulis pelajari terutama yang berkaitan dengan problema belajar anak. Di antaranya:

\section{Kesulitan Belajar}

Walaupun belum ada definisi yang baku mengenai anak berkesulitan belajar di Indonesia, namun dapat penulis ambil kesimpulannya sebgai berikut:

Anak berkesulitan belajar adalah anak yang secara nyata mengalami kesulitan dalam tugas-tugas akademik khusus maupun umum, baik di sebabkan oleh adanya disfungsi neurologis, proses psikologisdasa maupun sebab-sebab lain sehingga prestasi belajarnya rendah dan anak tersebut beresiko ketinggalan pengatahuan atau bahkan kelas. Anak berkesulitan belajar kemungkinan juga mengalami gangguan fisik, social dan mental ringan sehingga cukup mengganggu mereka dalam menangkap pelajaran (materi) jika di bangdingkan dengan yang tidak mengalami kesulitan belajar.

\section{Jenis anak dengan problema belajar \\ Kesulitan belajar Umum}

Anak berkesulitan belajar umum biasanya di tandai dengan prestasi belajar yang rendah untuk hampir semua maa pelajaranatau nilai rat-ratajauh di bawah rata-rata kelas sehingga mempunyai resiko cukup tinggi dalam melanjutkan ke jenjang selanjutnya. Kesulitan tersebut bukan di sebabkan karena IQ yang rendah, pada umumnya mereka memiliki IQ yang rata-rata bahkan ada yang di atas rata-rata. Anak yang seperti ini bisa disebut dengan anak yang lambat belajar.

\section{Kesulitan belajar Khusus}

Kesulitan beajar khusus dapat di kelompokkan menjadi dua jenis yaitu kesulitan belaajr pra akademik yang meliputi gangguan motoric dan persepsi, kesulitan belajar kognitif, gangguan perkembangan bahasa dan kesulitan dalam penyesuaian perilaku social. Sedangkan kesulitan belajr akademik yang meliputi kesulitan belajar membaca, menulis dan berhitung. 


\section{METODE PENELITIAN}

Metode penelitian ini menggunakan libarary research atau study literature. Yaitu penelitian yang menggabungkan berbagai infomasi yang berhubungan dengan tema maupun problem yang sedang di kaji. Sumber data yang di dapatkan dari penelitian ini yaitu menggunakan refrensi yang actual baik itu berupa artikel, buku atau data lapangan yang mengkaji tentang pendidikan anak dengan problema belajar.

\section{HASIL DAN PEMBAHASAN}

\section{Definisi Anak Dengan Problema Belajar}

Di sekolah-sekolah umum kita menjumpai siswa yang beraneka ragam, ada siswa yang cepat tanggap dalam belajar, ada siswa yang lamban dalam belajardi hamper semua mata pelajarana, ada siswa yang mengalamai kesulitan belajar untuk mata pelajaran tertentu, ada siswa yang dasar potensinya sebenarnya bagus tetapi prestasi belajarnya selalu rendah dan tentunya ada yang perkembangan belajarnya biasa-biasa saja. Menghadapi kondisi seperti itu, pada umumnya guru dalam proses belajar mengajar cxenderung hanya mendasarkan pada pemenuhan kebutuhan siswa rata-rata sedangkan siswa dengan kebutuhan belajar capat at au lamban cenderung terabaikan.

Kesulitan belajar menurut $\mathrm{H}$ Abin Syamsuddin adalah suatu kejaidan atau peristiwa yang menunjukan bahwa dalam mencapai tujuan pengajaran, sejumlah siswa mengalami kesulitan dalam menguasai bahan yang di pelajari.4 Sedangkan menurut Anton Sukarno menjelaskan bahwa kesulitan belajar yaitu sebagai pembeda kondisi fisik dalam intelejensi rata-rata sampai dengan system motorik sensorik dalam kesempatan belajar.

Jadi cakupan defenisi anak dengan problema belajar adalah anak yang karena satu hal lain secara signifikan menunjukan kesulitan dalam mengikuti pendidikan pada umumnya, tidak mampu mengambangkan potensinya secara optimal, prestasi belajar yang di capai berada di bawah potensinyasehingga mereka memerlukan perhatian dan pelayanan khusus untuk mendapatkan hasil yang terbaiksesuai dengan bakat dan kemampuannya. Anak yang mengalami gangguan atau kelainan fisik tertentu dank arena kelainannya tidak menyebabkan gangguan dalam mengikuti pendidikan biasa tidak termasuk anak dengan problema belajar, demikian juga anak berbakat. Akan tetapi jika kelainannya mereka mengalami kesulitan dalam oenyesuaian belajar, mereka termasuk dari kategori anak dengan problema belajar.

\section{Klasifikasi Anak Dengan Problema Belajar}

Ada beberapa klasifikasi anak dengan problema belajar. Di Indonesia diantara kelompok anak dengan kebutuhan khusus terdapat anak luas biasa. Anak luar biasa merupakan kelompok yang sudah jelas kedudukannya dalam undang-undang pasal 54 nomor 39 tahun 1999 di sebut berkelainan fisik dan/atau mental dan/atau perilaku. Mereka terdiri atas tuna netra , tuna rungu, tuna grahita, tuna daksa, tuna laras dan tuna ganda. Anak yang mempunyai kemampuan dan kecerdasan luar biasa tidak di kategorikan sebagai anak luar biasa. Mereka di akui sebagai anak yang memerlukan perhatian khusus, anak dengan problema belajar secara eksplisit di sebutkan dalam undang-undang tentang pendidikan.

\section{Faktor dan Gejala Anak Problema Belajar}

Ada beberapa factor dan gejala yang tampak secara umum pada anak dengan problema belajar, di antaranya adalah sebagai berikut: 


\section{Di lihat dari segi factor penyebab}

Anak mengalami problema belajar dapat di sebabkan oleh berbagai haldi antaranya sebagai berikut:

1. Factor intelektual

2. Factor kondisi fisik dan kesehatan, termasuk kondisi kelainan.

3. Factor social.

\section{Dilihat dari gejala yang tampak}

Anak dengan problema belajar sering menampakkan gejala dan cirri-ciri perilaku tertentu, diantaranya sebagai berikut:

1. Tidak dapat mengikuti pelajaran seperti yang lain

2. Sering terlambat atau tidak menyelasaikan tugas

3. Menghindari tugas-tugas yang berat

4. Ceroboh atau kurang teliti dalam banyak hal.

5. Acuh tak acuh at au masa bodoh

6. Menampakkan semangat belajar yang rendah

7. Tidak mampu berkosentrasi, berubah-rubah

8. Perhatian terhadap suatu objek singkat

9. Suka mnyendiri, sulit menyesuaikan

10. Murung

11. Suka memberontak, agresif, meledak-ledak dalam merespon ketidakcocokan

12. Hasil belajar rendah.

\section{Konsep Pendidikan anak dengan Problema belajar}

Suasana atau iklim belajar memiliki pengaruh yang sangat besar terhadap pencapaian system belajar yang optimal. Pengolaan kelas atau pengelolaan system pembelajaran sangat menekankan pentingnya pencipataan suasana belajar yang kondusif bagi pencapaian belajar yang kooperatif. Untuk itu di harapkan bagi para pendidik mampu memberikan pelayanan pendidikan kepada anak didik dengan problema belajar elalui pembelajaran kooperatif di kelas.

Seperti yang tertera dalam pandangan hidup Pancasila dan smboyan Bhineka Tunggal Ika, manusia pada hakikatnya adalah makhluk bhineka yang mengamban misi tunggal sebagai khalifah Tuhandi muka bumi. Pandangan hidup dan semboyan tersebut jga mengajarkan kepada bangsa Indonesia bahwa Tuhan mencitakan manusia berbeda-beda secara vertikan maupun horizontal agar dapat saling memanfatkan atau saling membantu, sehingga manusia dapat mengembangkan potensi kemanusiaan yang di miliki hingga taraf yang optimal dan terintegrasi.

Dengan mengaktualisasi potensi kemanusiaan yang optimal dan terintegrasi itulah manusia melaksanakanfungsi kekhalifahannya. Bertolak dari pandangan hidup dan semboyan semacam itu, bhineka vertical seperti kaya-miskin, kuat-lemah, pandai-bodoh dan bhineka horizontal seperti latar belakang budaya, agama, suku, ras, adat istiadat dan sebagainya di sikapi sebagai kondisi alami yang memungkinkan manusia berinteraksi dalam rangka saling membutuhkan atau menjalin hubungan kerja sama. Interaksi saling membutuhkan atau hubungan kerjasama antar anak di dalam kelas inilah menghasilkan suasa belajar kooperatif.

Kebhinekaan di pandang sbagai kondisi alami yang di ciptakan oleh Tuhan agar manusia dapat saling berhubungan dalam rangka membutuhkan. Oleh karena itu, pendidik hendaknya menciptakan suasana belajar kooperatif dalam kelas. Penciptaan suasana belajar kooperatif berarti pula menciptkan norma yang membuat semua anak memberikan sumbangan kemajuan kelompok. Norma semacam itu memandang anak yang mendominasi 
anak lain atau menggantungkan diri pada orang lain sama buruknya sehingga harus diberantas. Ini berarti anak yang pandai harus membantu anak yang kurang pandai , anak yang kuat harus membantu anak yang lemah dan tiap anak harus saling mendorong untuk menumbuhkan motivasi belajar yang kuat. Berbagai perilaku luhur sseperti di kemukakan bukan hanya sekedar di asumsikan dan di laksanakan hanya jika di ingat akan tetapi secara sengaja di ajarkan terus menerus

Ada empat elemen dasar yang memungkina terciptanya suasana belajar kooperatif. Elemen dasar tersebut adalah sebagai berikut:

\section{Saling ketergantungan positif}

Dalam pembelajaran kooperatif pendidik menciptakan suasana yang mendorong anak-anak merasa saling membutuhkan satu sama lain. Hubungan yang saling membutuhkan inilah yang di maksud dengan saling ketergantungan positif. Saling ketergantungan positif fapat di capai melalui saling ketergantungan tujuan, saling ketergantungan tugas, saling ketergantungan bahan atau sumber, saling ketergantungan peran dan saling ketergantungan hadir.

\section{Interaksi tatap muka}

Interaksi kooperatif anatar anak dalam kelompok belajar membuart mereka saling bertatao muka sehingga merekadapat melakukan dialog tidak hanya dengan pendidik tetapi juga dengan sesama meraka. Interaksi semacam it dapat memungkinkan anak-anak Saling menjadi sumber belajar. Anak-anak merasa sering lebih mudah belajar dari esamanya dari belajar dengan guru. Interaksi tatap muka memungkinkan terciptanya sumber belaajr yang bervariasi sehingga mengoptimalkan pencapaian hasil belejar.

\section{Akuntabilitas individual}

Pembelajaran kooperatif menampilkan wujud dalam belajar kelompok. Meskipun demikian penilaian di tujuka untul mengetahui penguasaan materi pelajaran tiap anggota kelompok dan hasil penilaian di komunikasikan kepada kelompok. D engan demikian, tiap anggota kelompok mengetahui siapa anggota yang perlu mendapatkan bantuan dan siapa yang di harapkan memebri bantuan. Nilai kelompok didasarkan atas rata-rata belajar semua anggota kelompok dank arena itu tia anggota kelonpok harus memberikan sumbangan demi kemajuan kelompok. Penilaian kelompok secara individual inilah yang di maksud dengan akuntabilitas individual.

\section{Keterampilan menjalin hubungan interpersonal.}

Pada pembelajaran kooperatif, keterampilan social seperti tenggang rsa, bekerja sama, bersikap sopan terhadap temn, mengkritik ide orang lain, berani memeprtahankan pikiran logis, tidak mendominasi orang lain, mandiri dan berbagai sifat lain yang bermanfaat untuk menjalin hubungan interpersonal tidak hanya di asumsikan tetapi di ajarkan secara sengaja. Anak yang tidak dapat menjalin hubungan interpersonal atau hubungan antar pribadi tidak hanya memperoleh teguran dari guru akan tetapi juga dari sesame teman.

\section{KESIMPULAN}

Berdasarkan uraian dalam tulisan ini, dapat kita fahami bahwa Anak berkesulitan belajar adalah anak yang secara nyata mengalami kesulitan dalam tugas-tugas akademik khusus maupun umum, baik di sebabkan oleh adanya disfungsi neurologis, proses psikologisdasa maupun sebab-sebab lain sehingga prestasi belajarnya rendah dan anak tersebut beresiko ketinggalan pengatahuan atau bahkan kelas. Hasil dari definisi yang di utarakan seperti yang di atas menghasilkan beberapa konsep tentang bagaimana pendidikan bagi anak dengan 
problema belajar, dan hasil tersebut menghasilkan konsep berupa metode pembelajaran secara kooperatif yang pada akhirnya konsep ini dapat mengakomodir kekurangan dari anak yang memiliki problema dalam belajar.

\section{DAFTAR PUSTAKA}

Abdurrahman, Mulyono, pendidikan bagi anak berkesulitan belajar, Jakarta: Gramedia, 2018. Andi Pratowo, Analisis pembelajaran Terpadu, Jogyakarta:Pustaka Setia, 2019.

Fisip, H. (2020, June). Prosiding Slamet Riyadi Conference On Public Administration (Sripa). In Prosiding: Slamet Riyadi Conference on Public Administration (SRIPA) (Vol. 2, No. 1).

M. Slamet Yahya, Pendidikan karakter melalui ideology, Jakarta: Lontar mediatama 2020,

M slamet Yahya, pendidikan karakter melalui budaya sekolah, Jakarta Lontar mediatama,2020,

Muhibbin Syah, Psikologi belajar, Jakarta:Gramedia 2019

M Slamet Yahya, pendidikan karakter melalui budaya sekolah, Jakarta Lontar mediatama,2020.

Pambudy, A. P., \& Syairozi, M. I. (2019). Analisis Peran Belanja Modal dan Investasi Swasta Terhadap Pertumbuhan Ekonomi Serta Dampaknya Pada Kesejahteraan Masyarakat. Jurnal Ekonomi dan Bisnis, 20(1), 26-39.

Susanti, I., Syairozi, M. I., \& Lukman, H. Y. W. (2021). Analisis Sistem Manajemen Dalam Pengelolaan Bumdes Di Desa Bluluk. Jurnal Sains Sosio Humaniora, 5(2), 701-710.

Syairozi, M. (2015). Pengaruh Faktor Eksternal (Inflasi, Bunga) Dan Faktor Internal (Bagi Hasil, Jumlah Bank) Terhadap Deposito Mudharabah Pada Perbankan Syariah Di Indonesia (Doctoral dissertation, Universitas Brawijaya).

Syairozi, M. I., \& Susanti, I. (2018). Analisis Jumlah Pengangguran dan Ketenagakerjaan terhadap Keberadaan Usaha Mikro Kecil dan Menengah di Kabupaten Pasuruan. Jurnal Samudra Ekonomi dan Bisnis, 9(2), 198-208. 